\title{
PENERAPAN PERANGKAT PEMBELAJARAN IPS MODEL THINK-PAIR-SHARE (TPS) DENGAN MEDIA VIDEO UNTUK MENINGKATKAN KARAKTER, AKTIVITAS DAN HASIL BELAJAR SISWA
}

\author{
Novi Setyasto \\ Jurusan PGSD, Universitas Negeri Semarang \\ E-mail : novisetyasto@mail.unnes.ac.id \\ Bayu Wijayama \\ SDN Sadeng 03 Kota Semarang \\ E-mail : bayuwijayama@gmail.com
}

\begin{abstract}
Abstrak
Berdasarkan hasil observasi awal di SDN Sadeng 03 ditemukan masalah dalam pembelajaran IPS di kelas V. Siswa merasa kesulitan dalam menghafal tokoh-tokoh atau pelaku sejarah, tempat, dan waktu kejadian sehingga hasil belajar siswa rendah dan kurang aktif dalam pembelajaran. Penelitian ini adalah penelitian tindakan kelas yang terbagi menjadi tiga siklus. Penelitian ini bertujuan untuk meningkatkan karakter, aktivitas, dan hasil belajar siswa dengan mengimplementasikan perangkat pembelajaran yang sudah dikembangkan dengan model TPS dan media video. Sample penelitian ini berjumlah 23 siswa kelas V. Data diperoleh melalui observasi, tes, catatan lapangan, dan dokumentasi. Teknik analisis data smenggunakan analisis deskriptif kualitatif dan kuantitatif. Hasil penelitian menunjukkan bahwa perangkat pembelajaran efektif untuk menanamkan karakter pada siswa yang ditunjukkan dengan peningkatan skor karakter dari 27,3 (Siklus 1), 27,8 (Siklus 2), dan 28,9 (Siklus 3). Selain itu, aktivitas siswa juga mengalami peningkatan yang ditunjukkan dengan peningkatan aktifitas dari kategori tinggi (siklus 1) menjadi kategori sangat tinggi pada Siklus 1 dan Siklus 2. Penerapan perangkat pembelajaran juga berhasil meningkatkan hasil belajar siswa yang dibuktikan dengan peningkatan skor rata-rata hasil belajar IPS siswa dari 55 (Pra siklus) menjadi 81 (Siklus 3). Berdasarkan data tersebut dapat disimpulkan bahwa penerapan perangkat pembelajaran model TPS dengan media video efektif untuk meningkatkan karakter, aktivitas, dan hasil belajar siswa kelas V SDN Sadeng 03.
\end{abstract}

Kata Kunci: perangkat pembelajaran, TPS, media video, hasil belajar.

\begin{abstract}
Based on preliminary observation in Sadeng 03 Semarang elementary school has been found some challenges which needed to be overcome in the learning process of social studies, especially in $5^{\text {th }}$ grade students. Students often face difficulties to memorize historical people, places, time, and events which happened in the past. Thus, their learning outcomes were low and they tended to be passive learners. This was classroom action research which was divided into three cycles. This study aimed to enhance students' characters, activities, and learning outcomes by applying the learning tools which have been developed using TPS model and video media. The samples of this research were 23 students of $5^{\text {th }}$ grade. Data was derived from observation, test, field note, and documentation. Qualitative and quantitative description were used in this research. The results showed that the learning tools were effective to foster students' characters which showed by the increase of their characters' score of $27.3\left(1^{\text {st }}\right.$ cycle $), 27.8\left(2^{\text {nd }}\right.$ cycle $)$, and $28.9\left(3^{\text {rd }}\right.$ cycle). Their implementation also could improve students' activities proved by the improvements of students' activities form $1^{\text {st }}$ cycle (high category) to the $2^{\text {nd }}$ and $3^{\text {rd }}$ cycle (very high category). In addition, there were found improvements of students' learning outcomes in every cycle which showed by the increases of average scores from 55 (pre-cycle) to 81 ( $3^{\text {rd }}$ cycle). In conclusion, the learning tools using TPS Model and Video Media were effective to level up the students' characters, activities, and learning outcomes of social studies in $5^{\text {th }}$ grade of Sadeng 03 elementary school.
\end{abstract}

Keywords: learning tools, TPS, video media, learning outcomes. 


\section{PENDAHULUAN}

\section{1) Latar Belakang}

Tujuan pembelajaran IPS di SD sebagaimana diamanatkan dalam Peraturan Menteri Pendidikan Nasional Nomor 22 tahun 2006 tentang Standar Isi adalah mengarahkan peserta didik untuk dapat menjadi warga Negara Indonesia yang demokratis dan bertanggung jawab, serta warga dunia yang cinta damai. Mata pelajaran IPS dirancang untuk mengembangkan pengetahuan, pemahaman, dan kemampuan analisis terhadap kondisi sosial masyarakat dalam memasuki kehidupan bermasyarakat yang dinamis (KTSP 2006).

Untuk mendorong tercapainya tujuan pendidikan nasional yang di dalamnya termaktub tujuan IPS, dikeluarkanlah Permendiknas No. 41 tahun 2007 tentang standar proses yang menyebutkan bahwa pembelajaran pada setiap satuan pendidikan dasar dan menengah harus interaktif, inspiratif, menyenangkan, menantang, dan memotivasi peserta didik untuk berpatisipasi aktif. Implikasi dari prinsip ini adalah pergeseran paradigma pendidikan, yaitu dari paradigma pengajaran ke paradigma pembelajaran.

Dikeluarkannya Permendiknas No. 41 tahun 2007 tersebut juga dikarenakan bahwa selama ini pembelajaran yang berpusat pada peserta didik (student centered) belum mampu diwujudkan secara optimal terutama di tingkat sekolah dasar. Sebagaimana yang diungkapkan Sanusi dalam (Winataputra 2008), pengajaran IPS di sekolah cenderung menitikberatkan pada penguasaan hafalan, proses pembelajaran yang masih terpusat pada guru (teacher centered), dan kurangnya pemanfaatan sumber belajar yang ada, sehingga situasi pembelajaran membosankan peserta didik. Menurut (Zhao \& Hoge 2005), peserta didik paling merasa kesulitan pada konsep sejarah yang abstrak berkaitan dengan waktu atau tempat karena guru dalam pembelajaran konsep IPS tidak menyediakan aktivitas kontekstual yang berkaitan dengan pengalaman yang sudah dimiliki peserta didik sebelumnya (Wade 2002), dalam penelitiannya mengungkapkan $75 \%$ sampai $90 \%$ waktu pembelajaran IPS beracuan pada buku pelajaran sehingga peserta didik menjadi pasif dan membuat konsep IPS tampak asing bagi peserta didik.

Studi pendahuluan yang dilakukan di SD Negeri Sadeng 03 menunjukkan bahwa perangkat pembelajaran IPS yang digunakan masih kurang sesuai dengan standar proses, yaitu silabus dan RPP yang digunakan masih sederhana belum berpusat pada peserta didik dan belum memaparkan kegiatan eksplorasi, elaborasi, dan konfirmasi secara jelas. Hasil observasi pada saat pembelajaran IPS menunjukkan guru masih mendominasi pembelajaran (teacher centered), penggunaan model pembelajaran masih kurang tepat belum sesuai dengan keadaan peserta didik, yaitu guru masih menyampaikan informasi dengan metode ceramah berpanduan pada buku ajar IPS yang ada, serta belum maksimalnya penggunaan media menyebabkan peserta didik kurang aktif dan cepat merasa bosan, guru hanya menggunakan media gambar seadanya padahal SD Negeri Kemasan sudah memiliki perangkat pendukung seperti laptop, LCD, layar, dan sound system. Partisipasi peserta didik pun rendah yaitu cenderung pasif dan kurang konsentrasi karena peserta didik hanya mendengarkan penjelasan guru dan dibantu dengan media gambar seadaanya, kemudian mengerjakan soal yang diberikan. Mata pelajaran IPS di kelas V cakupan materinya sangat luas dan lebih cenderung pada pembelajaran sejarah. Peserta didik sering merasa kesulitan dalam menghafal tokoh-tokoh atau pelaku sejarah, tempat, dan waktu kejadian. Hal-hal tersebut mengakibatkan tingkat pemahaman peserta didik terhadap materi rendah, yang berdampak pada hasil belajar peserta didik menjadi rendah. Hal tersebut dibuktikan dengan hasil ulangan siswa pada semester satu, dari 23 siswa hanya 10 orang yang mencapai kriteria ketuntasan minimal $(K K M=60)$ dan rata-rata skor hasil belajar adalah 55. Sebagai dampaknya sangat diperlukan usaha peningkatan hasil belajar dan aktivitas siswa melalui penelitian tindakan kelas.

\section{2) Kajian Pustaka}

Terkait dengan permasalahan pembelajaran yang berpusat pada peserta didik, (Lie 2005) menyarankan penggunaan model kooperatif tipe think-pair-share yang memberi kesempatan lebih kepada peserta didik untuk bekerja sendiri sekaligus bekerjasama dengan teman lainnya. Selain itu think-pair-share juga dapat mengoptimalisasi partisipasi peserta didik. Think-pairshare merupakan salah satu teknik pembelajaran kooperatif yang disebut sebagai model multi siklus diskusi, dimana peserta didik mendengarkan sebuah pertanyaan atau presentasi, kemudian peserta didik mendapatkan waktu berpikir individual, berbicara satu sama lain dalam pasangan dan pada akhirnya membagi pendapat pada kelompok yang lebih besar (Lyman \& Mctighe 1988).

Menurut teori perkembangan kognitif (Piaget 2001), peserta didik usia SD berada pada tahap operasional konkret (7-11 tahun), pada tahap ini seorang anak dapat membuat kesimpulan dari sesuatu pada situasi nyata atau dengan menggunakan benda konkret, dan mampu mempertimbangkan dua aspek dari situasi nyata secara bersama-sama (misalnya, antara bentuk dan ukuran). Oleh karena itu dalam pembelajaran haruslah disesuaikan dengan menggunakan benda-benda konkret (media dalam pembelajaran). Kenyataan di lapangan materi IPS pada kelas V SD cenderung lebih banyak mengandung sejarah 
dan bersifat abstrak sehingga diperlukan media untuk membuat konsep menjadi lebih konkret dan mudah dipahami oleh peserta didik. Penelitian ini menggunakan media video. Media video adalah segala sesuatu yang memungkinkan sinyal audio dapat dikombinasikan dengan gambar bergerak secara sekuensial. Keunggulan media video yang mampu menampilkan gambar bergerak dan suara merupakan satu daya tarik tersendiri, karena peserta didik mampu menyerap pesan atau informasi dengan menggunakan lebih dari satu indera. Selain itu media video mengatasi keterbatasan ruang, waktu, tenaga, dan daya indra (Daryanto 2010). Media video yang melibatkan suara (audio) dan gambar (visual) dapat mendorong meningkatnya pemahaman, ingatan, penguasaan, dan pembelajaran lebih mendalam daripada penggunaan media tunggal audio atau media visual saja (Berk 2009).

Penelitian tindakan kelas ini menggunakan perangkat pembelajaran yang telah dikembangkan oleh (Setyasto 2014) melalui R\&D. Proses pengembangan perangkat sudah disesuaikan dengan Standar Proses dan menggunakan model TPS dan media video. Perangkat pembelajaran terdiri dari: 1) silabus, 2) rencana pelaksanaan pembelajaran (RPP), 3) lembar kerja peserta didik (LKPD), 4) media video, 5) perangkat penilaian hasil belajar (PPHB), dan 6) buku petunjuk guru (BPG). Perangkat ini sudah diuji coba di SDN Kemasan dan terbukti berhasil meningkatkan aktivitas, karakter, dan hasil belajar siswa dalam pembelajaran IPS di kelas V.

\section{3) Tujuan}

Penelitian ini bertujuan untuk meningkatkan aktivitas, karakter, dan hasil belajar siswa kelas V SDN Sadeng 03 melalui penerapan perangkat pembelajaran model TPS dengan media video.

\section{METODE}

Penelitian ini adalah penelitian tindakan kelas (PTK) yang terdiri dari empat tahapan utama yaitu: 1) perencanaan, 2) tindakan, 3) observasi, 4) refleksi (Arikunto 2006). PTK ini dilakukan dalam 3 siklus. Sampel penelitian ini berjumlah 23 siswa kelas V SDN Sadeng 03 Kecamatan Gunungpati, Kota Semarang. Teknik pengumpulan data dilakukan dengan observasi, test, catatan lapangan, dan dokumentasi. Teknik analisis data menggunakan analisis deskriptif kualitatif dan kuantitatif.

\section{HASIL DAN PEMBAHASAN}

\section{A. Hasil Belajar Siswa}

Hasil belajar siswa diperoleh melalui tes yang diberikan kepada siswa tentang materi Peristiwa Proklamasi Kemerdekaan Indonesia dengan Standar Kompetensi (SK) adalah 2. Menghargai peranan tokoh pejuang dan masyarakat dalam mempersiapkan dan mempertahankan kemerdekaan Indonesia, dan Komptensi Dasar (KD) adalah 2.3 Menghargai peranan tokoh perjuangan dalam memproklamasikan kemerdekaan. KD tersebut diajarkan dalam 3 pertemuan pembelajaran dimana setiap pertemuan memiliki indikator dan tujuan pembelajaran yang berbeda. Hasil pembelajaran menunjukkan adanaya peningkatan hasi belajar siswa dari siklus 1 ke siklus 3 seperti yang ditunjukkan Gambar 1 .

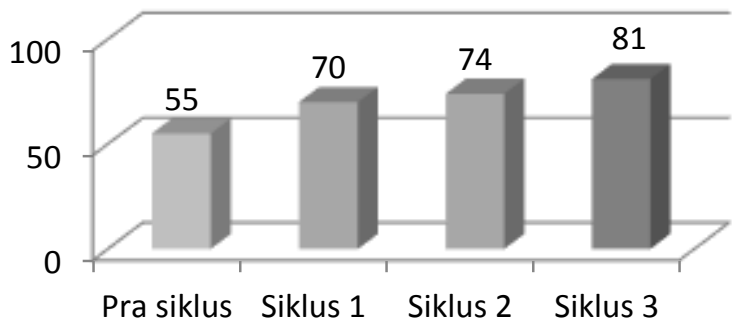

\section{Gambar 1. Peningkatan Skor Rata-rata Hasil Belajar}

Gambar 1 menunjukkan adanya peningkatan skor ratarata hasil belajar siswa dari pra-siklus atau sebelum diterapkan perangkat pembelajaran ke siklus 1, 2, dan 3 dimana sudah diterapkan perangkat pembelajaran TPS dengan media video. Hal tersebut dibuktikan dari rata-rata hasil belajar sebelumnya pada pra-siklus hanya 55 dan mengalami peningkatan pada siklus 1 (70), siklus 2 (74), dan meningkat menjadi 81 pada siklus 3 . Hal ini menunjukkan bahwa penerapan perangkat pembelajaran dapat meningkatkan rata-rata hasil belajar siswa pada mata pelajaran IPS. Sebagai tambahan, jumlah siswa yang berhasil mencapai KKM juga mengalami peningkatan dari siklus 1 ke siklus 3 sebagaimana ditunjukkan Gambar 2.

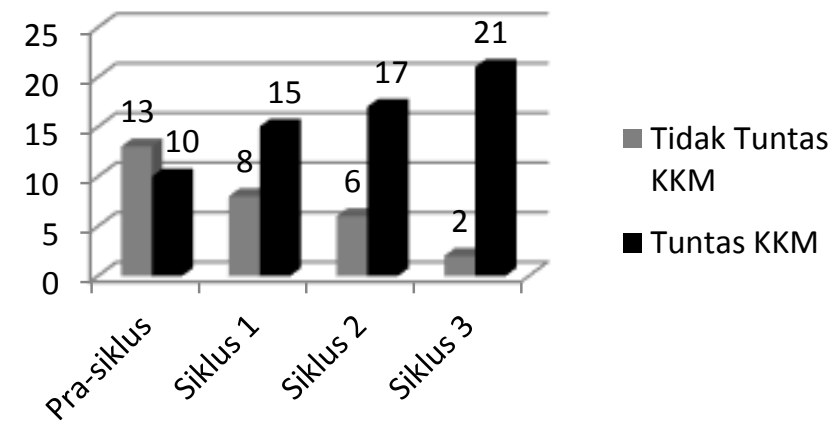

Gambar 2. Jumlah Siswa Tuntas KKM

Gambar 2 menunjukkan jumlah siswa dengan hasil belajar yang mencapai KKM dan siswa yang belum tuntas KKM dimulai dari pra-siklus sampai ke siklus 3 . Berdasarkan Gambar 2, jumlah siswa yang tidak tuntas KKM terbanyak adalah pada pra-siklus (13 siswa), dan secara bertahap jumlah tersebut mengalami penurunan pada siklus 1 (8 siswa), siklus 2 (6 siswa), dan akhirnya 
pada siklus 3 hanya terdapat 2 siswa yang tidak tuntas KKM. Sebaliknya, jumlah siswa dengan hasil belajar tuntas KKM meningkat dari hanya 10 siswa pada saat prasiklus, menjadi 15 siswa pada siklus 2, dan 17 siswa pada siklus 2, dan 21 dari 23 siswa berhasil mencapai KKM pada pembelajaran siklus 3. Berdasarkan hasil tersebut dapat dibuktikan bahwa penerapan perangkat pembelajaran TPS dengan media video efektif untuk meningkatkan hasil belajar siswa pada mata pelajaran IPS. Pada saat pra-siklus, guru tidak menggunakan perangkat pembelajaran TPS dengan media video, malahan guru hanya menggunakan buku teks dan gambar sederhana untuk mengajarkan materi IPS pada siswa. Hasil belajar yang diperoleh siswa jauh dari harapan, dimana hanya terdapat 10 dari 23 siswa yang tuntas KKM dan skor ratarata hasil belajar siswa hanya 55. Sebaliknya, dimulai dari siklus 1 menuju siklus 3, kondisi berubah karena perangkat pembelajaran model TPS dengan media video telah diterapkan dalam proses pembelajaran. Hasil belajar siswa mengalami peningkatan yang signifikan pada siklus 3 dengan 21 dari 23 siswa berhasil tuntas KKM dan skor rata-rata hasil belajar siswa mencapai 81 . Hasil ini sesuai dengan sebuah penelitian yang telah dilakukan oleh (Ifamuyiwa \& Onakoya 2008) di Ogun, Nigeria dengan sampel sejumlah 120 siswa. Hasil peneltian menunjukkan adanya pengaruh yang signifikan implementasi think-pairshare (TPS) terhadap hasil belajar siswa.

\section{B. Aktivitas Siswa}

Data aktifitas siswa diperoleh dari observasi dalam proses pembelajaran IPS pada siklus 1 , siklus 2, dan siklus 3. Indikator yang diamati terdiri dari 10 indikator, yaitu: 1) kesiapan siswa untuk belajar, 2) keterlibatan siswa dalam pembelajaran, 3) kemampuan siswa menyimak video, 4) kemampuan berpikir (think) siswa, 5) kemampuan siswa berpikir berpasangan (pair), 6) kemampuan siswa berbagi ide di depan kelas (share), 7) kemampuan siswa mengisi LKPD, 8) kemampuan siswa dalam bertanya, 9) kemampuan siswa membuat simpulan, dan 10) kemampuan siswa mengerjakan soal evaluasi. Hasil observasi menunjukkan adanya peningkatan aktifitas siswa dari siklus 1 menuju siklus 3 sebagaimana ditunjukkan Gambar 3.

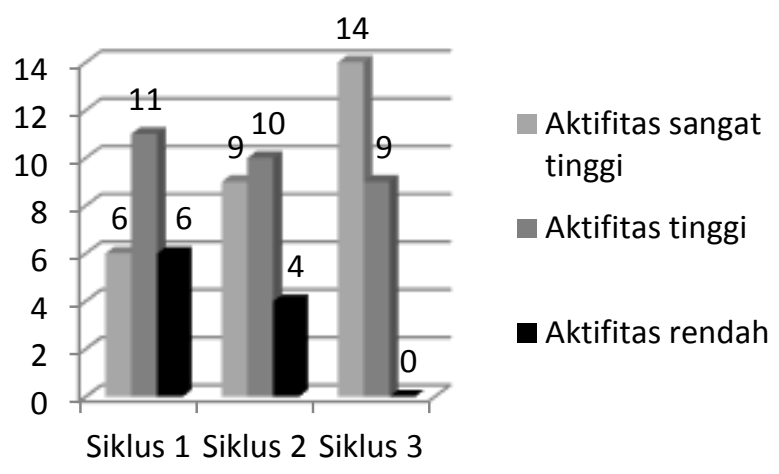

Gambar 3. Peningkatan Aktifitas Siswa

Gambar 3 menunjukkan peningkatan aktivitas siswa dalam proses pembelajaran IPS dari siklus 1 sampai siklus 3. Pada siklus 1, terdapat 6 siswa dengan kategori aktivitas sangat tinggi sedangkan 11 lainnya termasuk dalam kategori aktivitas tinggi dan masih terdapat sebanyak 6 siswa dengan aktivitas rendah. Hal ini disebabkan oleh kurangnya persiapan yang seharusnya dilakukan guru dalam pembelajaran. Guru membutuhkan waktu untuk menyesuaikan diri dengan perangkat pembelajaran baru, khususnya dalam penggunaan video sebagai media pembelajaran. Pada siklus 1, guru hanya memutar video satu kali dalam pembelajaran sehingga siswa masih kurang bisa memahami materi dan cerita secara jelas dan pada umumnya siswa masih merasa raguragu dan takut salah dalam menyampaikan pendapat karena sebelumnya mereka terbiasa berpedoman pada buku teks dan mendengarkan penjelasan dari guru. Pada siklus 2, jumlah siswa dengan kategori aktivitas sangat tinggi meningkat menjadi 9 orang sedangkan 10 siswa dengan kategori aktivitas tinggi, dan jumlah siswa dengan kategori aktivitas rendah mengalami penurunan menjadi 4 siswa. Siswa mulai menyesuaikan dan merasa familiar dengan penerapan perangkat pembelajaran dan siswa sudah memahami tahapan think-pair-share. Guru menampilkan video dua kali dalam pembelajaran sehingga siswa memahami lebih dalam tentang materi. Selanjutnya, pada siklus 3 , jumlah siswa dengan kategori aktifitas sangat tinggi meningkat menjadi 14, sedangkan 9 lainnya memiliki aktivitas dengan kategori tinggi. Hal ini disebabkan beberpa alasan, seperti: guru memberikan instruksi dengan jelas kepada siswa tentang tujuan pembelajaran dan apa yang harus dilakukan oleh siswa selama proses pembelajaran, siswa sudah familiar dengan perankat pembelajaran model TPS dengan media video dan mereka sudah memahami tentang penggunaan LKPD sebagai alat bantu dalam menyimak video, berpikir (think), berdiskusi berpasangan (pair), berbagi (share), dan membuat simpulan. Hal ini diperkuat dengan peningkatan skor rata-rata aktivitas siswa sebagaimana ditunjukkan Gambar 4. 


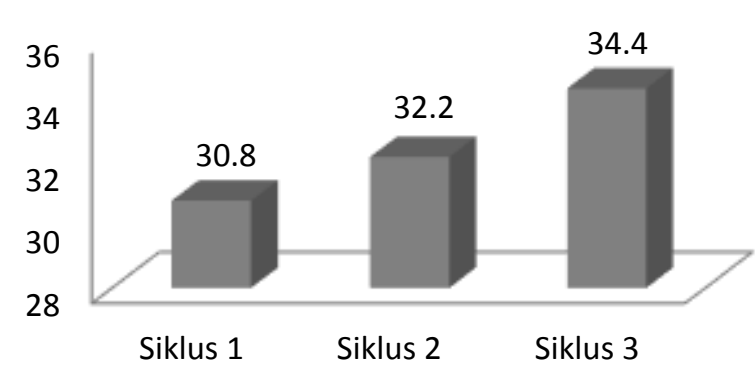

Gambar 4. Peningkatan Skor Rata-rata Aktifitas Siswa

Gambar 4 menunjukkan pada siklus 1, skor rata-rata aktivitas siswa adalah 30,8 dengan kategori tinggi dan pada sikulus 2 meningkat menjadi 32,2 dan pada siklus 3 meningkat menjadi 34,4 dengan kategori sangat tinggi. Hal ini menunjukkan bahwa penerapan perangkat pembelajaran model TPS dengan media video efektif meningkatkan aktivitas siswa dalam pembelajaran IPS. Hal ini sejalan dengan hasil penelitian yang dilakukan oleh (Lom 2012), TPS memberikan lebih banyak kesempatan dan memotivasi siswa untuk lebih terlibat secara aktif dalam proses pembelajaran.

\section{Karakter Siswa}

Data karakter siswa diperoleh melalui pengamatan dalam proses pembelajaran IPS pada siklus 1, siklus 2, dan siklus 3. Karakter yang diamati dalam penelitian ini terdiri dari 4 karakter, yaitu: 1) disiplin, 2) tanggung jawab, 3) menghargai, 4) cinta tanah air. Setiap karakter memiliki indikator masing-masing seperti yang ditampilkan pada Tabel 1 .

Tabel 1. Indikator Karakter

\begin{tabular}{|c|c|c|}
\hline No & Karakter & Indikator \\
\hline 1 & Disiplin & $\begin{array}{l}\text { 1. Disiplin dalam proses } \\
\text { pembelajaran } \\
\text { 2. Disiplin dalam mematuhi aturan } \\
\text { kelas }\end{array}$ \\
\hline 2 & $\begin{array}{l}\text { Tanggung } \\
\text { jawab }\end{array}$ & $\begin{array}{l}\text { 1. Tanggung jawab individu } \\
\text { 2. Tanggung jawab dalam kelompok }\end{array}$ \\
\hline 3 & Menghargai & $\begin{array}{l}\text { 1. Kemampuan siswa menghargai } \\
\text { teman } \\
\text { 2. Kemampuan siswa menghargai } \\
\text { guru } \\
\text { 3. Kemampuan siswa menghargai } \\
\text { pahlawan kemerdekaan }\end{array}$ \\
\hline 4 & $\begin{array}{l}\text { Cinta tanah } \\
\text { air }\end{array}$ & $\begin{array}{l}\text { 1. Kemampuan siswa dalam } \\
\text { menghargai, mencintai, dan } \\
\text { bangga terhadap Indonesia }\end{array}$ \\
\hline
\end{tabular}

Tabel 1 menunjukkan indikator-indikator karakter yang ditanamkan dalam pemikiran dan tindakan siswa melalui pembelajaran IPS. Hasil pengamatan menunjukkan adanya peningkatan skor karakter siswa dari siklus 1 sampai siklus 3 seperti yang ditampilkan Gambar 5.

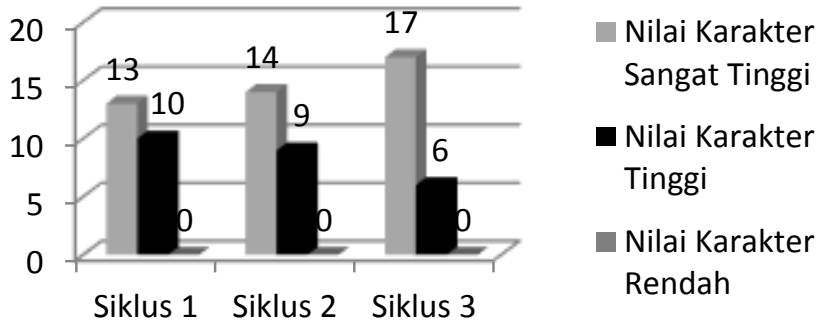

Gambar 5. Peningkatan Nilai Karakter Siswa

Gambar 5 menunjukkan peningkatan jumlah siswa yang mendapatkan nilai karakter dengan kategori sangat tinggi dari siklus 1 sampai siklus 3, yaitu 13 siswa pada siklus 1, 14 siswa pada siklus 2, dan meningkat jumlahnya menjadi 17 siswa pada siklus 3. Jumlah terbanyak terdapat pada siklus 3 karena adanya pemutaran video tentang materi menghargai tokoh-tokoh proklamasi kemerdekaan Indonesia sehingga karakter menghargai dan cinta tanah air bisa tampak. Dari ketiga siklus tidak terdapat siswa dengan nilai karakter rendah. Hal ini diperkuat dengan peningkatan rata-rata skor nilai karakter seperti yang ditunjukkan Gambar 6.

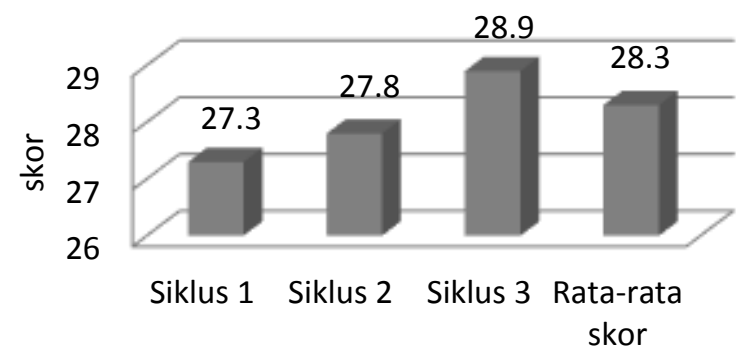

Gambar 6. Peningkatan Skor Rata-rata Karakter Siswa

Gambar 6 menunjukkan bahwa penerapan perangkat pembelajaran model TPS dengan media video efektif untuk meningkatkan nilai karakter siswa yang ditunjukkan dari skor rata-rata meningkat dari siklus $1(27,3)$, siklus 2 $(27,8)$ dan siklus $3(28,9)$ yang semuanya termasuk dalam kategori nilai karakter sangat tinggi. Hasil ini sejalan dengan hasil penelitian yang dilakukan oleh (Ferrer 2005) di empat sekolah dasar di Guam. Hasil penelitian menunjukkan bahwa penerapan model kooperatif dapat meningkatkan tanggung jawab, interaksi, dan penghargaan siswa terhadap teman dan guru.

\section{PENUTUP}

\section{Simpulan}

Perangkat pembelajaran IPS model TPS dengan media video dikembangkan sesuai dengan Standar Proses. Perangkat terdiri dari 6 macam, yaitu: 1) silabus, 2) rencana pelaksanaan pembelajaran (RPP), 3) lembar kerja 
peserta didik (LKPD), 4) media video, 5) perangkat penilaian hasil belajar (PPHB), dan 6) buku petunjuk guru (BPG). Penerapan perangkat pembelajaran di kelas V SDN Sadeng 03 efektif untuk meningkatkan nilai karakter siswa, yaitu disiplin, tangung jawab, menghargai, dan cinta tanah air. Aktifitas siswa dapat meningkat yang dibuktikan dengan peningkatan keterlibatan siswa dalam proses pembelajaran melalui proses think, pair, dan share. Hasil belajar siswa juga meningkat yang dibuktikan dengan peningkatan rata-rata hasil belajar tiap siklus, dari semula 55 pada pra-siklus menjadi 81 pada siklus ketiga. Berdasarkan data tersebut, dapat disimpulkan bahwa penerapan perangkat pembelajaran IPS model TPS dengan media video efektif untuk meningkatkan nilai karakter, aktivitas, dan hasil belajar siswa kelas V khususnya SDN Sadeng 03.

\section{Saran}

Perlunya penelitian lanjutan untuk penerapan perangkat pembelajaran model TPS dengan media video pada pembelajaran di SD dengan skala yang lebih luas seperti pada beberapa SD dalam satu gugus atau bahkan kota.

\section{DAFTAR PUSTAKA}

Arikunto, S., 2006. Penelitian Tindakan Kelas, Jakarta: Bumi Aksara.

Berk, R.A., 2009. Multimedia Teaching with Video Clips: TV, Movies, You Tube, and mtvU in The College Classroom. International Journal of Technology in Teaching and Learning, 5 (1), pp.121.

Daryanto, 2010. Media Pembelajaran, Yogyakarta: Gava Media.

Ferrer, L.M., 2005. Developing Understanding and Social Skills through Cooperative Learning. Journal of Science and Mathemathics Education in S.E. Asia, 27 (2), pp.45-61.

Ifamuyiwa, A.S. \& Onakoya, S.K., 2008. Impact of Think-Pair-Share Instructional Strategy on Students' Achievement in Secondary School Mathematics. Journal of the Science Teachers Association of Nigeria, 48(1), pp.26-34.

KTSP, 2006. Standar Isi dan Standar Kompetensi Kelulusan Untuk Satuan Pendidikan Dasar SD/MI, Jakarta: BP Cipta Jaya.

Lie, A., 2005. Cooperative Learning, Jakarta: PT Grasindo.

Lom, B., 2012. Classroom Activities: Simple Strategies to Incorporate Student-Centered Within Undergraduate Sciences Lectures. The
International Journal of Undergraduate Neuroscience Education, 11 (1), pp.A64-A71.

Lyman, F.T. \& Mctighe, J., 1988. Cueing Thinking in the Classroom: The Promise of Theory-Embedded Tools. Journal Eductional Leadership, pp.18-24.

Piaget, J., 2001. The Psychology of Intelligence, London $\&$ New York: Routledge Classics.

Setyasto, N., 2014. Pengembangan Perangkat Pembelajaran IPS Model Kooperatif Tipe ThinkPair-Share dengan Media Video untuk Kelas V SD. Universitas Negeri Semarang.

Wade, R., 2002. Beyond Expanding Horizons: New Curriculum Directions for Elemetary Social Studies. The Elementary School Journal, 103 (2), pp.116-130.

Winataputra, U.S., 2008. Materi dan Pembelajaran IPS $S D$, Jakarta: Universitas Terbuka.

Zhao, Y. \& Hoge, J.D., 2005. What Elementary Students and Teachers Say about Social Studies. The Social Studies, 96(5), pp.216-221. 